\title{
Recenzja monografii "Emocje dzieci i młodzieży z trudnościami w rozwoju i zachowaniu" (redakcja naukowa Barbara Winczura), wydawnictwo Oficyna Wydawnicza "Impuls", Kraków 2017
}

Dziwne to, ale prawdziwe - w polskiej literaturze poświęconej osobom z zaburzeniami rozwoju nie było dotąd solidnego opracowania odnoszącego się do przeżywanych emocji przez te osoby. Co więcej, w literaturze światowej także niewiele można znaleźć książek na ten temat. Fakt ten powinien skłaniać nas do zastanowienia: dlaczego powstało mnóstwo książek poświęconych jakości życia, przystosowaniu, akceptacji siebie, zaburzeniom procesów poznawczych, integracji społecznej, a o emocjach dzieci niepełnosprawnych pisze się tak niewiele? Czyżby to był problem marginesowy $\mathrm{w}$ życiu tych osób? A może wszystko co trzeba wiedzieć w tej sprawie, już wiemy? Wreszcie może być i tak, że moda na spoglądanie na problemy życiowe osób niepełnosprawnych przez okulary, w których jedno ze szkieł można określić kognitywizmem, a drugie psychologią pozytywną sprawia, że po prostu nie widzimy problemów, które są tak oczywiste i tak powszechne, że są prawie niezauważalne? Postawione pytania mają oczywiście charakter retoryczny. W każdym z nich można znaleźć odpowiedź prawdziwą. Brak zainteresowania emocjami osób z dysfunkcjami rozwojowymi wynika pewnie z jeszcze jednego powodu po prostu problematyka rozwoju emocjonalnego i jego zaburzeń jest wyjątkowo trudna, jeśli chodzi o prowadzenie badań, które spełniałyby obowiązujące standardy naukowe i dlatego stosunkowo mała liczba badaczy podejmuje się badań w tym zakresie. 
W świetle powyższych uwag należy więc docenić wartość monografii opracowanej pod redakcją naukową Barbary Winczury, poświęconej w całości sprawie emocji doświadczanych przez dzieci i młodzież niepełnosprawną. Często piszemy o nowych książkach naukowych, że zapełniają one jakąś lukę w naszej dotychczasowej wiedzy. W przypadku opiniowanej książki nie jest to jednak standardowy ogólnik. Opracowanie Emocje dzieci i młodzieży z trudnościami w rozwoju i zachowaniu rzeczywiście dostarcza wiedzy, jakiej dotąd nie było, a zapotrzebowanie na nią jest ogromne wśród rodziców dzieci niepełnosprawnych, ich nauczycieli, pedagogów specjalnych, psychologów i lekarzy pediatrów. Trudno sobie wyobrazić, żeby bez wiedzy o przeżywanych emocjach można było skutecznie wspierać rozwój dzieci niepełnosprawnych. Emocje mogą pomagać we wszechstronnym rozwoju wszystkich dzieci, ale też mogą go skutecznie blokować. W przypadku dzieci niepełnosprawnych powyższa teza także jest prawdziwa. W tym jednak przypadku emocje częściej pełnią funkcję negatywną, jeśli chodzi o rozwój dysfunkcjonalny. Chcąc więc zmniejszyć negatywną funkcję emocji, trzeba dokładnie poznać emocjonalne mechanizmy psychologiczne, które same w sobie mogą być zaburzone, ale również mogą oddziaływać na inne sfery rozwojowe dziecka niepełnosprawnego. Pięknie opisała ten problem we Wstępie do omawianej książki Profesor Krystyna Ferenz, a więc nie ma potrzeby, abym jeszcze dodatkowo uzasadniał znaczenie zagadnień. Dodam może tylko, że pisanie książki na temat, który nie jest zbyt dobrze rozpoznany, wymagał wyjątkowego wysiłku (poszukiwanie odpowiedniej literatury) i odpowiedzialności (pionierskie prace są jak fundament, na którym będzie budowany w dalszym ciągu gmach wiedzy, a więc chodzi o to, żeby ten fundament był solidny).

Omawiana publikacja jest bardzo solidnym opracowaniem naukowym. $\mathrm{Z}$ pewnością jest to zasługą dobrze dobranych autorów poszczególnych rozdziałów. Każdy z nich nie jest tylko „molem książkowym”, który zna problem emocji osób niepełnosprawnych od strony teoretycznej. Łatwo można zorientować się, czytając kolejne rozdziały, że zaczynając od pierwszej autorki - Hanny Kubiak, do ostatniej - Sylwii Wrony, wszyscy twórcy musieli mieć doświadczenie praktyczne z dziedziny, o której piszą. A poza tym łatwo wyczytać, że problemy, które poruszają, nie są im obojętne. Piszą o nich $\mathrm{z}$ dużym zaangażowaniem (nie przekraczają jednak standardów naukowych), a jednocześnie prezentują tą szczególną postawę wobec osób niepełnosprawnych, która można nazwać postawą humanistyczną co również jest ogromną wartością całego opracowania. Poza tym każdy 
rozdział jest dobrym przeglądem wiedzy teoretycznej (niestety niezbyt bogatej, co tylko potwierdza, że badania nad emocjami należy zintensyfikować) oraz wyników badań empirycznych, oświetlających z różnych stron życie emocjonalne dzieci i młodzieży z dysfunkcjami rozwojowymi.

Recenzowana książka jest pracą zbiorową. Nie znaczy to jednak, że składa się ona z luźno i mało logicznie powiązanych ze sobą rozdziałów. Należy wyraźnie uwypuklić istotny wkład redaktorki książki, polegający na tym, że przygotowała całość w bardzo spójny sposób, Książka składa się z dwóch części. Pierwsza poświęcona jest charakterystyce różnych stanów i mechanizmów działania emocji - depresji, lęku, wstydu i innych. Dobrze stało się także, że ta część rozpoczyna się od omówienia prominentnej obecnie koncepcji przywiązania, która może mieć wyjątkowe znaczenie, jeśli chodzi o wyjaśnianie i rozumienie trudności związanych z rozwojem emocjonalnym osób niepełnosprawnych w przyszłości. Druga część książki poświęcona jest analizie przeżyć emocjonalnych dzieci i młodzieży z różnymi rodzajami niepełnosprawności: chorych przewlekle, niepełnosprawnych umysłowo, niewidomych i słabo widzących, z uszkodzeniami słuchu oraz z autyzmem. Oczywiście nie są to wszystkie możliwe dysfunkcje rozwojowe, ale niewątpliwie te, które zostały omówione, należy uznać za najważniejsze. Wskazany układ książki sprawia, że jej struktura jest logiczna i w pełni zrozumiała.

Podsumowując, opiniowana książka jest bardzo cennym wzbogaceniem dotychczasowej literatury psychopedagogicznej ponieważ: a) spełnia ona w pełni zapotrzebowanie praktyki pedagogicznej na wiedzę w o funkcjonowaniu emocjonalnym dzieci i młodzieży z zaburzeniami rozwojowymi; b) omówienie wyników badań i tez teoretycznych związanych z emocjami doświadczanymi przez te osoby, wykonane zostało na wysokim poziomie naukowym (podkreślam obiektywizm i rzetelność przeprowadzonych analiz); c) całość została dobrze przemyślana przez redaktorkę opracowania, zarówno jeśli chodzi o dobór zaproszonych autorów do współpracy, jak również układ wszystkich rozdziałów. Książka w całości wyróżnia się poziomem naukowym, opracowania trudnego zagadnienia emocji doświadczanych przez osoby z zaburzeniami rozwoju.

prof. dr hab. Stanisław Kowalik Uniwersytet Zielonogórski DOI: https://doi.org/10.14746/ikps.2018.22.22 